\title{
Feasibility of a Carbon Consumption Tax for sustainable development - A case study of India
}

\author{
* Dr. Singh Kanwal Deepinder Pal 1 \\ 1 University School of Law and Legal Studies, Guru Gobind Singh Indraprastha University New Delhi, India \\ E mail: kdps@ipu.ac.in
}

\section{A R T I C LE INF O:}

Article history:

Received 2 August 2017

Accepted 8 October 2017

Available online 12 October 2017

\section{Keywords:}

Carbon Consumption Tax;

Sustainable development;

Global climate

change;

India

This work is licensed under a Creative Commons Attribution

NonCommercial - NoDerivs 4.0. "CC-BY-NC-ND"

\begin{abstract}
A B S T R A C T
Global climate change is a major issue confronting policymakers worldwide, and there is widespread scientific acceptance of the reality of climate change and its adverse consequences In terms of economic analysis, greenhouse gas emissions $(G H G)$, which cause planetary climate changes, represent both an environmental externality and the overuse of a common property resource. The paper is premised around the hypothesis that tax policy can be used to address climate concerns by making less Green House Gas intensive purchases and investments more financially attractive. However, in the absence of an international framework capping GHG emissions, countries adopting mitigation policies incur costs that would not exist under global cooperation such as the loss of competitiveness and emissions leakage. A consumption tax based on the carbon footprint of a product levied on all products at the point of purchase by the final end-user, regardless of where the goods are produced using a Credit-method would be capable of addressing these concerns of emissions leakage and loss of competitiveness, while being WTO compliant. The author intends to test the feasibility and effectiveness of such a carbon consumption tax in the Indian Context. The author shall test the feasibility of levy of such a consumption tax in the context of India and evaluate the effectiveness in mitigating climate change and catering to the goal of sustainable development. JOURNAL OF CONTEMPORARY URBAN AFFAIRS (2017) 1(3), 18-23.
\end{abstract}

https://doi.org/10.25034/ijcua.2018.3674

www.ijcua.com

Copyright (C) 2017 Journal Of Contemporary Urban Affairs. All rights reserved.

\section{Introduction}

Climate change is a major environmental issue that is affecting the policy decisions worldwide. The world is aware of this grim reality and adverse consequences of global warming (Harris, et al., 2015) Greenhouse gas emissions (GHG), cause climate changes, and are adversely affecting economies also. This is because of overuse of a common property resource. (Harris, et al., 2015). The paper is premised around the hypothesis that tax policy can be used to address climate concerns by making less GHG intensive purchases and investments financially attractive. (Moarif, and Rastogi, 2012). However, in the absence of an international framework capping GHG emissions, countries adopting mitigation policies incur costs that would not exist under global cooperation such as the loss of competitiveness and emissions leakage. A consumption tax based on the carbon footprint of a product levied on all products at the point of purchase by the final end-user, regardless of where the goods are produced would be

\footnotetext{
*Corresponding Author:

University School of Law and Legal Studies, Guru Gobind Singh Indraprastha University New Delhi, India

E-mail address: kdps@ipu.ac.in
} 
capable of addressing these concerns of emissions leakage and loss of competitiveness, while also being WTO compliant. The paper intends to test the feasibility and effectiveness of such a carbon consumption tax in the Indian context. The author shall test the feasibility of levy of such a consumption tax in the context of India and evaluate the effectiveness in mitigating climate change and catering to the goal of sustainable development.

A carbon tax is a levy imposed on fossil fuels and other primary products based on the amount of GHG they emit. To explain it with an example, carbon tax places a fee on coal, proportionate to the amount of carbon dioxide (CO2) released when coal is burned. This tax can also be seen as a cost for emitting GHGs into the atmosphere. The environmental friendly people can also use it as a financial incentive for reducing $\mathrm{GHG}$ emissions. A carbon tax policy can also be designed to include tax credits for activities that reduce GHGs in the atmosphere.

A carbon tax can also be seen as explicit carbon pricing because it is a tax linked to the level of carbon dioxide (CO2) emissions. This can be used as an economic instrument and can contribute to an effective reduction in emissions. The carbon tax is a price on each tonne of GHG emitted, and therefore the price signal causes a response in an entire economy. The emitters feel that it would be economically beneficial to shift to less GHG method production and this feeling of profitability results in reduced emissions. Carbon taxes can be introduced independently or alongside other carbon pricing instrument, like an energy tax. Introduction of a direct carbon tax is a new concept, but its acceptability is coming at a fast pace. (Congressional Budget Office Policy Options for Reducing CO2 Emissions, 2012.). A carbon tax can also be seen as an alternative or a supplement to a cap-andtrade program.

A carbon tax and a cap-and-trade program are both market-based and have a concept of financial incentive to reduce GHG emissions. The main difference between the two concepts is on the establishment of price and reduction of emissions. A carbon tax imposes a direct levy called the "carbon price" on activity based on the amount of GHGs they emit. It puts no restriction on GHG emissions. On the other hand, the cap-and-trade program sets a limit, or "cap," on emissions, but the price for emission is determined by the demand and supply. Current climatic conditions force a relook on existing policy efforts related to global warming issues.
The main premise of this paper is a plan that provides clean environment by the introduction of a small carbon tax or a GHG tax. The proceeds of this tax could be used to support research efforts on energy sources, energy use, and reduction of emission. The scenario prevailing in different countries is examined along with the position in India. The evidence shows that carbon taxes may be an interesting policy option and that their main negative impacts may be compensated through the design of the tax and the proper use of the generated revenues.

\section{International Legal Scenario}

Kyoto Protocol was earlier considered to be the strongest international agreement on the topic of climate change wherein 182 nations had committed to minimizing GHGs. Critics of the Kyoto Protocol felt that it was premised on setting national emissions targets and did not deal with the actual problem of global warming caused by emissions. It also created "common but differentiated responsibilities." It put little to no responsibility for developing nations to check emissions. Unchecked growth of emissions in the developing world was having a larger impact on the environment. It was beginning to overcome the developed world, the best example being India and China. Countries like Canada and Russia feel that it was not a way forward, and declined to take on additional obligations. Dealing with these issues is expensive and inconvenient, and it carries high monetary and sociological costs. Cost of environmental degradation already has a negative effect on the economy. There is a need for international coordination on environmental issues as much as international coordination is required in trade liberalization.

Carbon taxes are seen as a cost-effective instrument for reducing emissions. However, in practice, only a few countries have implemented taxes based on the carbon content of energy products. Some countries that have imposed carbon taxes are discussed subsequently. The methodology adopted by them in discussed briefly so as to weigh it in relation to the Indian scenario.

In British Columbia, carbon tax applies to the purchase or use of fuels. This tax is revenue neutral, and all funds generated by the tax are used to provide reductions to citizens for other taxes. Denmark imposed a carbon tax in 2014 covering consumption of natural gas, oil, and coal. There are partial exemption and refund for 
EU coverage and certain other activities. Fuels used in the production of electricity are not subject to the carbon tax. But there is a tax on production of electricity. French parliament approved consumption tax on energy products in December 2013. It is based on the content of $\mathrm{CO} 2$ in consumption of fossil fuel. On the consumption of gas, heavy fuel oil, and coal carbon tax was imposed in 2014. In 2015 carbon tax was extended to transport fuels and heating oil. In Iceland importers of gas and diesel oils, petrol, aircraft, and jet fuels are liable for the carbon tax. It is also applicable to retail use. The funds collected are deposited in the treasury In Ireland the carbon tax applies to petrol, heavy oil, auto-diesel, kerosene, liquid petroleum gas (LPG), fuel oil, natural gas, and coal since 2010. In Japan, CO2 emission factor is used for each sector since 2012. It has imposed a levy named Japan's Tax for Climate Change Mitigation on use of fossil fuels. In May 2013 the South African government published a policy paper for public comment on before introducing a carbon tax. The government has introduced a fuel input tax based on the carbon content of the fuel. It covered all direct GHG emissions and had been imposed from January 2016. Sweden introduced a carbon tax in 1991. It was a part of energy sector reform, and tax was imposed on natural gas, gasoline, and coal, Switzerland introduced carbon since 2008, and this tax is applicable on all fossil fuels. They are exempted if they are used for energy. The United .Kingdom has introduced carbon price floor (CPF) tax on fossil fuels used to generate electricity since 2013. This changed the Climate Change Levy (CCL) regime, by applying carbon price support (CPS) rates of CCL to gas, solid fuels, and liquefied petroleum gas (LPG) used in electricity generation. (OECD Environment Policy paper, 2013).

\section{Utility of carbon tax and its impact}

World economists understand that to reduce the impact of climate change; it is necessary to tax production and use of fossil fuels. The taxation scheme should encourage efficient use of existing resources so that the negative result of such uses is reduced. A tax would lower fossil fuel consumption as they become more expensive. It will make it cost efficient and also encourage the use of alternative technologies. It leads to internalizing the costs of emissions. Carbon taxes affect all industry with the capacity to pollute, but the burden falls upon the energy and transportation sectors. Therefore it is advisable to levy it on all sectors as needed.

\subsection{Impact of carbon tax on companies}

Companies and individuals pay higher prices for GHG-intensive energy. Costs of a carbon tax are passed down to consumers. High energy prices impact the overall income of companies and individuals. This impact is dependent on the utility of tax revenues. The overall impact also depends on the use of energy, and on the ability of the company to minimize costs. This can be done by using clean fuel and by making the carbon tax "revenue neutral." This can also be done through rebates or changes in the tax code like reducing capital gains taxes. A carbon tax policy can also make provisions to provide funding for research or transportation infrastructure (Stef, and Van Dender, 2011).

\subsection{Impact on lower-income consumers}

Impact of a carbon tax on lower-income consumers depends on the use of tax revenues. A basic carbon tax is regressive. Lower-income consumers pay a higher percentage of their total income for goods and services (Lin, and Li, 2011 ). Some carbon tax programs address this by "recycling" tax revenues. or allow reductions in other regressive taxes, such as state sales taxes or federal payroll taxes.

\subsection{Impact on international competitiveness}

Impacts on an industry depend on the level of the tax, recycling of revenue, use of energy by the industry and competitiveness of the industry. The competitiveness varies by sector. One thought process treats it as cost penalty for doing business whereas the other line of thought feels that a carbon tax encourages innovation and efficiency. This leads to long-term competitiveness.

Environmental challenges, like climate change, and pollution, occur when there is a burden on the assimilative capacity of environmental resources. If a society is affected by pollution, and the polluter is not held accountable for it, then all this cost of pollution is not reflected in the final prices of the goods and services. This leads to market failure and government intervention. The government regulates it or introduces market-based instruments. These instruments influence the decision-making processes of producers and consumers. (Liv, et al., 2015). The government may also regulate by formulating emissions standards, levying taxes, or allocating pollution rights and granting subsidies to contribute to cleaning the environment. Marketbased instruments set a price on the pollution 
causing market distortion, IPCC (2013). A carbon price can drive changes in producer and consumer behavior, and can address climate change. Carbon pricing encourages a shift to low-carbon and energy-efficient technologies. This requires replacement with low-carbonemitting alternatives and mitigation and adaptation strategies (Burniaux et al., 2010). A carbon price also creates an environment for research, development and technology innovation. It reduces the price gap between carbon-intensive technologies and low-carbon alternatives.

\section{Indian Scenario}

The Government of India published its response to climate change in June 2010 which was titled "India: Taking on climate change." The government has approved the Perform, Achieve, and Trade (PAT) mechanism for energy efficiency. The first cycle of this mechanism commenced in 2014-15. This scheme works towards enhancing cost-effectiveness through tradable energy saving certificates (ESCerts) (Cropper et al., 2012). The PAT scheme covers 478 energy consumers, representing 40 percent of total industrial consumption in sectors like thermal power, steel, cement, fertilizer, pulp and paper, textile, aluminum and chlor-alkali. National Action Plan on Climate Change has been formulated which provides for generating 20000 MW of solar power by 2022 and 2000 MW from off-grid solar plants. India's Green initiative has been part of International Solar Alliance (ISA) that will provide a special platform for mutual cooperation among 121 solar-resource-rich countries lying fully or partially between the Tropic of Cancer and Tropic of Capricorn. India aims to have 40 percent cumulative electric power from non-fossil fuel- based energy resources by 2030. India has cut subsidies and increased taxes on fossil fuels. This is the movement from carbon subsidy to carbon taxes. Fossil fuel subsidy on diesel and petrol has been phased out, and reforms are being carried out in kerosene and LPG subsidies. The government of India has decontrolled diesel prices. Excise duty on petrol and diesel has been increased periodically to match the declining global prices. Since October 2014, excise duties have been imposed on diesel and petrol. Also, the coal cess has been continuously increased from 50 per ton to 400 per ton.

Excise duties on petrol or diesel act as an implicit carbon tax. They put an effective price on emissions. For example, more fuel car burns, and the greater the emissions, the greater the tax paid. In India, the change from subsidization to the taxation of fossil fuels is related to revenue and macro-economic considerations. They also impact climate change. This is important in the context of global efforts to deal with climate change because India is the third largest emitter of GHG emission.

While India has made substantial progress recently in decontrolling price of petrol and diesel and in calibrating excise duty to compensate for the declining world oil prices, there is still room for further reform of petroleum pricing policies (Schipper et al., 1997).

\section{Translating coal cess into carbon tax to GST compensation}

Recently, the Government of India revised its coal cess from 50 per ton to 400 per ton. Translating this into a carbon tax equivalent using the emission factor, the government is able to mop up a significant amount of revenue. Any rationalization of coal pricing must take account of the implications for power prices and hence access to energy for the poorest in India which is and must remain a fundamental objective of policy.

Since Modi took office in 2014, the coal cess has been raised with an idea was to dedicate the revenue to greening the economy. However, only $37 \%$ of the money collected between 2010 and 2017 was allocated to the clean energy and environment fund. The rest sat idle, creating a surplus that reached 56,700 crore rupees $(\$ 8.8$ billion) at the beginning of this financial year, more than 20 times the annual budget of the environment ministry. That surplus has now been allocated to compensate states that will lose out in the GST reform. More than 1 lakh crore rupees $(\$ 15.5 \mathrm{bn})$ of revenue due to being channeled into clean energy over the next five years will go the same way.

About 55 ongoing clean energy projects will continue to be funded through general taxation, "But this fund, for now, is over. After five years the government can rethink if it wants to spend $50 \%$ of the cess collected again for renewable energy and environment." GST, a big blow to clean energy financing. It was India's carbon tax; it was thought to be a source of funding clean energy projects, to combat climate change. Now it is being thrown out of the window. In the last six years, the government of India has 
collected around Rs 54,000 crore by levying a cess on every tonne of coal mined or imported.

\section{Conclusion}

International coordination is the prerequisite to deal with climate change. There should be an international regime of harmonized domestic carbon taxes. If there is a minimum amount of taxation on domestic producers, the revenue can be used for setting up of alternative means of energy production (Washington DC. World Bank, 2012). This shall also overcome the problem of non-participation of countries in agreements like the Kyoto Protocol. There are large ramifications of emitting harsh pollutants into the air. Though these supplies are supplies are cheap and come from long-utilized sources these options do not have longevity (Holden et al., 2016). Human actions have caused too many environmental disasters. Although the states would like to choose the use of resources to produce electricity their primary duty is to look after health and welfare of citizens. Use of cheap power plants is holding the states from meeting their responsibilities. This reflects a monumental threat" to the prosperity of the greatest number for the longest time. Reducing carbon dioxide emissions and mitigating climate change, the states can ensure best for their citizens best serve the people. To ensure the greatest good for future generations, society must take responsibility for its actions-starting now (Pachauri, and. Reisinger, 2007).

India has turned a carbon subsidy regime into one of carbon taxation. This has increased petrol and diesel price and reduced annual harmful emissions. India has to go a long way to get the gains from reform of coal pricing and petroleum pricing policies. Substantial carbon taxation and solar power program can lead to substantial contributions to climate change by India. Climate policies can also influence the, but the amount of influence shall depend upon a policy of exchange rate. A fixed exchange rate is beneficial for the economy.

The rapid development of the renewable energy sector is also very important for India to turn into a green economy. The costs of mitigation policies can be more if affordable renewable energy is absent.

To reduce emission levels, the renewable energy sector needs to grow, and carbon mitigation policies are required. Technological and financial resources are required to develop the renewable energy sector. Emission trading permits can also be a source of finance. The level of emissions needs to be lower than the allowance. If emissions are higher than the allowance, the country will have to buy permits, involving the outflow of capital. Therefore, the choice of mitigation strategy is important. To conclude the transition to a green economy depends crucially on the rapid development of the renewable energy sector and the design of appropriate carbon mitigation policies (Basanta, and Ghosh, 2013).

\section{Acknowledgement}

This research did not receive any specific grant from funding agencies in the public, commercial, or not-for-profit sectors.

\section{References}

Basanta K., and Ghosh, P.J. (2013). The Impact of Carbon Taxes on Growth Emissions and Welfare in India: A CGE analysis I. Retrieved from

www.iegindia.org/upload/publication/Wor kpap/wp315.pdf IEG Working Paper No. 315G Working Paper No.

Burniaux, J.M., Chateau, J. and Duval, R. (2010). Is there a Case for Carbon-Based Border Tax Adjustment? An Applied General Equilibrium Analysisll. OECD Economics Department Working Papers 794.Paris, France: OECD Publishing

Congressional Budget Office Policy Options for Reducing CO2 Emissions. (2012). Retrieved from

http://www.cbo.gov/ftpdocs/89xx/doc893 4/02-12-Carbon.pdf last accessed on 06.07.2017

Cropper. M., Gamkhar, S., Malik, K., Limonov, A., and Partridge, I. (2012). The Health Effects of Coal Electricity Generation in India. RFF Working Paper.

Harris, M. J., Roach, B., and Codur, M. A. (2015) The Economics of Global Climate Change. Global Development and Environment Institute Tufts University. Retrieved from http://www.ase.tufts.edu/gdae/education _materials/modules/The_Economics _of_Global_Climate_Change.pdf last accessed on 04.10.2016.

Holden, E., Harball, E., \& Gilmer, E.M. (2016). SCOTUS halts Clean Power Plan, stuns states planning carbon cuts. E\&E PUBLISHING

IPCC (2013). Climate Change 2013, -The Physical Science Basis. Working Group I Contribution to the IPCC Fifth Assessment Report, Summary for Policymakers, 
Intergovernmental Panel on Climate Change, Geneva.

Lin, B.Q., Li, X.H. (2011). The Effect of Carbon Tax on Per Capita CO2 Emissions. Energy Policy, 39(9), 5137-46.

Liu, X.B., Wang, C., Niu, D.J. (2015), -An Analysis of Company Choice Preference to Carbon Tax Policy in China. Journal of Clean Prod; doi:10.1016/j.jclepro.2014.12.084.

Moarif, S., Rastogi, N.P. (2012). Market-based climate mitigation policies in emerging economies, Center for Climate and Energy Solutions.

Retrieved

from http://www.c2es.org/docUploads/marketbased-climate-mitigation-policiesemerging-economies.pdf last accessed on 04.10.2016.

OECD Environment Policy paper. (2013). Climate and Carbon Aligning prices and policies.
Pachauri, R.K and. Reisinger A. (2007). Climate Change 2007, -Synthesis Report, Contribution of Working Groups I, II and III to the Fourth Assessment Report of the Intergovernmental Panel on Climate Change. Geneva:IPCC,

Stef, P. and Van Dender, K. (2011). What Longterm Road Transport Future? Trends and Policy Options. Review of Environmental Economics and Policy, 5(1): 44-65.

Schipper, L., Ting, M., Khrushch, M., Golove, W. (1997), -The Evolution of Carbon Dioxide Emissions from Energy Use in Industrialized Countries: An End-Use Analysisll. Energy Policy, 25 (7), 651-672.

Washington DC. World Bank. (2012). $4^{\circ}$ Turn Down the Heat: Why a $4^{\circ}$ Warmer World Must Be Avoided. Washington DC., USA: World Bank 